\title{
MEMBANGUN KINERJA USAHA MELALUI FAKTOR PEMBENTUK KAPABILITAS PELAKU KEWIRAUSAHAAN INDUSTRI KREATIF NASIONAL
}

\author{
Iwan Hermawan \\ Departemen Administrasi Bisnis Terapan, Politeknik Negeri Semarang \\ iwanpolines@gmail.com \\ VS Tripriyo PS \\ Program Doktor Fakultas Ekonomi, Universitas Diponegoro \\ vs_tripriyo_ps@yahoo.com
}

\begin{abstract}
One of national creative industry roadmap key aspect is the character capability of businessmen. This research aims to empirically define the factors forming the entrepreneurial capabilities of creative industries and its impact on business performance. Art and creative technology industries in three cities in Indonesia, including Denpasar, Jogjakarta and Surakarta are used as samples. The factor analysis is employed to define the presence of three factors-which forming capabilities of national entrepreneurial creative industries, including: (1) internal management-risk management, (2) independence and anti-plagiarism design, and (3) the unique design and renewable idea. The statistic test finds the significant influence of entrepreneurial capabilities of creative industries on business performance. While internal management-risk management is the dominant factor contributing the business performance. Some other findings are national entrepreneurs have understood that the concept, idea, and knowledge were the main capital to accelerate the national creative economy. The entrepreneurs also understand the importance of self-reliance and anti-plagiarism design. But on the other hand, the majority of them have dominant of the external locus of control.
\end{abstract}

Keywords: entrepreneurship capabilities, creative industries, business performance, factor analysis

\section{PENDAHULUAN}

Kemunculan zaman ekonomi kreatif sebelumnya telah diramalkan Alvin Toffler dalam Future Shock (1970) yang menyatakan bahwa gelombang peradaban manusia itu dibagi tiga gelombang, meliputi fase abad pertanian, gelombang kedua abad industri dan gelombang ketiga abad informasi. Sementara pandangan Toffler berhenti disini, teori-teori terus berkembang dimana peradaban dengan kompetisi 
global yang ketat, pada akhirnya mendorong munculnya era peradaban baru gelombang keempat. Era baru peradaban ekonomi ini disebut knowledge-based economy (ekonomi berorientasi pada kreativitas).

Lahirnya knowledge-based economy (ekonomi kreatif) yang bermula dari paradigma industri kreatif muncul ke permukaan diawali dari pesatnya perkembangan Internet, ilmu pengetahuan dan teknologi, sehingga hal ini mendorong berubahnya dinamika pemetaan arah industri secara global membentuk ekonomi kreatif. Konsep ekonomi kreatif adalah kegiatan ekonomi dengan input dan output berupa adalah gagasan, yang mana peran pembentuk ekonomi kreatif dikendalikan oleh hukum kekayaan intelektual (paten, hak cipta, merek, royalti dan desain). Ekonomi kreatif terdiri dari kelompok profesional. Mereka yang berada di dalam industri kreatif memberikan kontribusi terhadap garis depan inovasi, sehingga ekonomi kreatif dapat dikatakan sebagai sistem transaksi penawaran dan permintaan yang bersumber pada kegiatan ekonomi dari industri kreatif. Industri kreatif berfokus terhadap penciptaan nilai melalui daya kreativitas. Gagasan dan ide merupakan kunci utama dalam industri kreatif, sehingga gagasan ini menjadi aset kunci. Industri kreatif adalah industri yang merujuk pada berbagai aktivitas ekonomi yang melakukan eksploitasi pada aspek pengatahuan dan informasi. Dalam beberapa variasi definisi, industri kreatif juga dianggap sebagai industri budaya (Hesmondhalgh 2002). Eksistensi industri kreatif menjadi menjadi semakin penting untuk membentuk kesejahteraan ekonomi, dimana kreativitas manusia adalah sumber daya ekonomi utama (Florida 2002). Industri juga akan semakin bergantung pada pengetahuan melalui munculnya kreativitas dan inovasi (Landry dan Bianchini 1995). Pada sisi lain, nilai keekonomian dari suatu produk atau jasa di era ekonomi kreatif tidak lagi ditentukan oleh bahan baku atau sistem produksi seperti pada era industri, tetapi pada pemanfaatan kreativitas dan inovasi.

Industri kreatif nasional sebagai pembentuk iklim ekonomi kreatif menunjukkan perkembangan kontribusi PDB yang cukup signifikan (4,75 persen) dengan serapan tenaga kerja sebesar 3.702.447 orang pada kurun 2002-2006. Kendatipun pada krisis ekonomi global 2009 industri kreatif Indonesia tetap tumbuh 1,5 persen. Nilai ekspor industri kreatif dalam kurun waktu tersebut mencapai Rp81,4 Triliun (9,13 persen) dari total ekspor nasional. Pertumbuhan ekspor terbesar dari industri fashion dan kerajinan, dengan kontribusi net trade 2002-2010 mencapai 65,26 persen. Produk Domestik Bruto (PDB) Indonesia tahun 2013 adalah sebesar 9.109.129,4 Miliar Rupiah, yang meningkat dari tahun sebelumnya 2012 sebesar 8.241.864,3 Miliar Rupiah. Kedua PDB tersebut mengindikasikan pertumbuhan sebesar sebesar 10,52 persen. Sementara ini, sektor ekonomi kreatif memberikan kontribusi sebesar 641.815,4 Miliar Rupiah atau 7,04 persen dari total PDB. Kontribusi ini menempatkan sektor ekonomi kreatif di peringkat ketujuh dari sepuluh sektor ekonomi. Sektor ekonomi kreatif sendiri mengalami peningkatan pertumbuhan 10,9 persen (Indonesia kreatif 2013). Industri kreatif di Indonesia sudah direspon 
pemerintah dengan membentuk peta jalan industri kreatif nasional, namun relatif tertinggal apabila dibandingkan dengan negara-negara maju di Asia, Amerika dan Eropa yang telah mengekspor produk kreatif mereka dibidang perfilman, musik, game, seni maupun inovasi teknologi. Dari fakta dan deskripsi data tersebut di atas, hal yang bersifat esensial dalam model pengembangan peta jalan industri kreatif Indonesia adalah terciptanya akselerasi yang mendorong laju pertumbuhan industri yang berdaya saing. Hal ini menjadi penting dalam rangka mengejar ketertinggalan Indonesia terhadap eksistensi produk-produk industri kreatif yang berasal dari negara-negara lain.

Dalam sudut pandang industri kreatif, saat ini industri tidak dapat lagi bersaing di pasar global dengan hanya mengandalkan harga atau mutu produk saja, tetapi bersaing berbasiskan inovasi, kreativitas dan imajinasi (Simatupang 2008). Demikian pula pada lingkup mikro kewirausahaan yang merupakan unit pembentuk industri. Konsep kreatif dan bisnis kewirausahaan akan memberikan domain prioritas yang harus didefinisikan dalam perencanaan bisnis, dimana dalam kewirausahaan, seringkali memunculkan polemik tarik-menarik kepentingan atas produk, antara pelaku wirausaha dengan pekerja yang menciptakan produk seni. Pekerja seni mendesain langsung produk mereka dengan cita rasa dan imajinasi seni mereka. Ide kreatif yang tertuang didominasi atas nilai seni produk yang bersifat tidak terikat dan bebas dalam ekspresinya, lebih dominan daripada nilai ekonomi berupa uang. Namun dari sudut pandang manajemen wirausaha, aspek komersial produk lebih dikedepankan daripada hanya sekedar membuat produk seni, atau jika memungkinkan kedua nilai manfaat dari aspek seni dan komersial (HKU 2010). Sebenarnya polemik yang sering muncul dalam lingkup mikro kewirausahaan seperti ini dapat dijembatani dengan merumuskan karakter dan kapabilitas seorang wirausaha industri kreatif. Karakter dan kapabilitas tersebut menekankan pada konsep munculnya ide produk baru dan selalu terbarukan sebagai discovery dan inovasi produk, wirausaha yang bersikap proaktif serta wirausaha yang berani mengambil risiko dalam konteks bisnis kewirausahaan industri kreatif.

Bisnis kewirausahaan memberikan kecenderungan organisasi untuk berinovasi dengan menyesuaikan kondisi pasar yang diminati, mengambil risiko untuk mencoba produk industri kreatif yang baru, layanan yang maksimal dan memperluas pasar yang lebih proaktif dibandingkan pesaing sehingga menciptakan peluang pasar baru. Para peneliti telah sepakat bahwa orientasi kewirausahaan merupakan kombinasi dari tiga dimensi yaitu: inovasi, proaktif dan berani mengambil risiko (Wiklund dan Shepherd 2005). Inovasi mencerminkan kecenderungan munculnya ide-ide baru, kebaruan proses dan produk kreatif. Proaktif mengacu pada postur melakukan antisipasi dan bekerja bagi pemenuhan kebutuhan pasar kedepan. Proaktif akan membuat wirausaha industri kreatif menggunakan pengetahuan mereka untuk melihat dan memahami kebutuhan masa depan pasar. Berani mengambil risiko dikaitkan dengan kemauan untuk melakukan pengelolaan 
sejumlah besar sumber daya yang diinvestasikan pada proyek kewirausahaan dengan risiko munculnya biaya kegagalan menjadi minimal. Keberanian pengambilan risiko akan mendorong organisasi untuk bereksperimen dengan suatu pengetahuan baru (Singh dan McKeen 2006). Faktor kunci utama dalam pengembangan industri kreatif adalah membangun karakter pelaku wirausaha nasional untuk berbagi pengetahuan dan munculnya komitmen nasionalisme dengan memasukkan konten budaya yang melibatkan kearifan lokal di lingkungan sekitarnya pada atribut produk kreatif yang dibuatnya (Hermawan et al., 2014).

Aspek strategis kajian penelitian ini adalah untuk mendefinisikan kondisi saat ini dari karakter pelaku wirusaha industri kreatif di Indonesia, dalam dimensi aspek pengetahuan, teknologi, pola pikir, integritas nasionalisme serta gaya hidup mereka menjadi suatu rumusan empiris. Manfaat dari penelitian yang dilakukan adalah memberikan bukti ilmiah mengenai kontribusi dari kapabilitas wirusaha nasional serta dampaknya pada kinerja usaha mereka. Definisi empiris ini selanjutnya dapat dijadikan dasar rujukan dan rambu-rambu pada pembuatan kerangka kerja peta jalan industri kreatif nasional.

Faktor kunci pembentuk daya saing industri kreatif nasional adalah pentingnya regulasi yang secara teknis membentuk karakter perilaku bisnis pengusaha nasional. Industri kreatif Indonesia relatif tertinggal dibandingkan dengan negara-negara maju, sehingga dalam implementasinya dibutuhkan adanya akselerasi percepatan industri kreatif nasional. Akselerasi diperoleh pada manajemen pengetahuan, berupa komitmen untuk berbagi pengetahuan. Namun pada sisi lain ternyata rendahnya kemauan dan keinginan berbagi dari pelaku industri kreatif di Indonesia, menjadi faktor penghambat akselerasi (Hermawan et al., 2014). Berangkat dari fakta tersebut, selanjutnya dikembangkan tujuan penelitian berikut.

a) Mengkaji secara empiris mengenai faktor-faktor pembentuk kapabilitas kewirausahaan dari pelaku industri kreatif pada kota-kota yang ditetapkan pemerintah sebagai kota kreatif, yaitu Denpasar, Yogjakarta dan Surakarta, dengan definisi karakter yang diturunkan kembali dari karakter inovasi, proaktif dan berani mengambil risiko (Wiklund dan Shepherd 2005), serta karakter lainnya yang digali dari penelitian sebelumnya.

b) Merumuskan model empiris dari pengaruh faktor-faktor kapabilitas yang terbentuk terhadap kinerja usaha industri kreatif nasional.

c) Mendeskripsikan kondisi existing dari gaya hidup pelaku industri keatif, baik dalam hal komitmen mengadopsi desain bernuansa lokal, tingkat kecemasan menggunakan teknologi, karakter kebangsaan maupun konsep dari prinsipprinsip kemandirian ide (anti-plagiasi).

Perumusan aspek empiris dalam penelitian ini akan dapat menjadi dasar empiris mengenai kontribusi dari kapabilitas wirausaha nasional serta dampaknya pada kinerja usaha mereka. Kapabilitas dan karakter wirausaha industri kreatif akan 
terfaktorkan dalam dimensi aspek pengetahuan, teknologi, pola pikir, integritas nasionalisme serta gaya hidup. Definisi model empiris yang dirumuskan ini selanjutnya dapat dijadikan dasar rujukan dalam kerangka kerja peta jalan industri kreatif. Regulasi teknis yang membangun kebersamaan dan berbagi pengetahuan pada industri kreatif sebagai faktor kunci kritikal dalam menciptakan akselerasi kinerja industri kreatif nasional yang mendorong nilai-nilai integritas kebangsaan, kemandirian ide serta kepedulian pada wirausaha kreatif sejenis.

\section{KAJIAN PUSTAKA DAN PENGEMBANGAN HIPOTESIS}

\section{Kapabilitas Kewirausahaan}

Kapabilitas wirausaha yang meliputi kapabilitas individu dan keahlian sosial, mendasarkan pada pemanfaatan segenap aset sumber daya usaha dan meramunya untuk menjadi produk yang dapat ditampilkan di pasar (HKU 2010). Dalam konteks kapabilitas kewirausahaan, hal yang menjadi tantangan adalah menciptakan inovasi dari aset kreatif dan menangkap peluang pasar, dimana keterampilan ini bersifat unik tetapi menyertakan jaringan dan koneksi. Wirausahawan adalah mereka yang melakukan upaya-upaya kreatif dan inovatif dengan jalan mengembangkan ide, merumuskan sumber daya yang ada untuk menemukan peluang dan perbaikan hidup (Prawirokusumo 1997). Kewirausahaan muncul apabila seseorang individu berani mengembangkan usaha-usaha dan ide-ide barunya. Proses kewirausahaan adalah suatu proses dalam mengerjakan sesuatu yang kreatif dan berbeda yang bermanfaat dalam memberikan nilai lebih. Kewirausahaan adalah kemampuan untuk menciptakan sesuatu yang baru dan berbeda (Drucker 1985). Jiwa dan karakteristik kewirausahaan melekat pada setiap individu yang menyukai perubahan, pembaruan, kemajuan dan tantangan serta orang-orang yang memiliki kreativitas dan inovasi yang tinggi dalam hidupnya. Sehingga secara epistimologis, kewirausahaan hakikatnya adalah suatu kemampuan yang tertuang dalam pola berpikir kreatif dan berperilaku inovatif dalam menghadapi tantangan hidup dengan berorientasi pada kesukesan melalui suatu perencanaan yang matang. Intinya, seorang wirausahawan adalah orang-orang yang memiliki jiwa wirausaha dan mengaplikasikan hakekat kewirausahaan dalam hidupnya. Kewirausahaan pada industri kreatif adalah wirausaha yang selalu dituntut memiliki ide-ide kreatif dengan konsep komersial dan dengan tujuan untuk mendapatkan profit. Pada kewirusahaan industri kreatif terdapat percampuran antara sisi kewirausahaan dan sisi kreatif. Konsepsi untuk berwirausaha di bidang industri kreatif seringkali dilakukan dengan mengadopsi aspek budaya lingkungan dan bangsa yang kental melekat pada desain produknya. Beberapa penelitian sebelumnya telah membentuk model karakteristik kewirusahaan dalam rangka memberikan pemahaman sistematis wirausaha dalam lingkungan industri kreatif. Termasuk didalamnya adalah beberapa kajian kewirausahaan yang berusaha membentuk definisi umum dengan mengelaborasi aspek budaya dan kreatif. Namun 
hal ini masih merupakan aspek tersulit, karena istilah "budaya" dan "kreatif" akan dibangun dengan melintasi wacana budaya-kearifan lokal dan tantangan ekonomi yang berkembang (HKU 2010).

Dalam kewirausahaan industri kreatif, munculnya profit yang signifikan adalah penting, akan tetapi bukan menjadi penggerak utama dalam organisasi kewirausahaan. Kreativitaslah yang menjadi faktor penggerak utama karena dengan munculnya kreativitas memungkinkan organisasi wirausaha untuk membangun kebaruan pada produk yang dilempar di pasar, melakukan pemenuhan diri karakter individu wirausaha atau bahkan mampu mengejar pemenuhan atribut produk yang inovatif dan kreatif. Konsep dan karakter individu terikat erat dengan locus of control. Locus of control akan mengacu pada sejauh mana individu dapat mengontrol peristiwa yang memengaruhi mereka yang bermula dikembangkan oleh Rotter (1954) dan selanjutnya menjadi aspek studi kepribadian. Locus seseorang dikonseptualisasikan dalam bentuk internal, artinya bahwa individu percaya mereka dapat mengontrol hidup mereka atau bentuk eksternal, artinya individu percaya keputusan dan kehidupan dikendalikan oleh faktor lingkungan yang mereka tidak bisa mereka pengaruhi, atau secara kebetulan atau nasib. Individu dengan internal locus of control yang kuat percaya bahwa peristiwa dalam kehidupan mereka terutama berasal dari tindakan mereka sendiri misalnya, seorang wirausaha yang menerima profit kinerja usahanya akan merasa berbanding lurus dengan jerih payah dan usaha yang dilakukan sebelumnya. Individu dengan locus of control internal cenderung memuji atau menyalahkan diri sendiri atas kemampuan mereka pada hasil akhir yang didapatkannya, sebaliknya individu dengan locus of control eksternal yang kuat cenderung memuji atau menyalahkan faktor eksternal pada individu lain, relasi maupun nasib (Carlson et al., 2007). Penelitian Sofyan et al. (2011) menegaskan kembali pentingnya aspek locus of control dalam merancang program pengembangan industri kreatif.

Dinamika kewirausahaan industri kreatif dewasa ini membutuhkan berbagai dukungan strategic, tergantung pada sifat lingkungan dan subsektor industri dimana mereka beroperasi. Dari kajian teoretis tersebut di atas, selanjutnya aspek kewirausahaan pada industri kreatif dalam penelitian ini merumuskan 15 aspek kapabilitas karakter wirausaha, seperti berikut: a) kuatnya inovasi untuk menciptakan daya beda, b) inovasi membuat desain yang belum pernah ada, c) komitmen memenuhi akad kontrak kerja, d) komitmen pemenuhan waktu deadline, e) gagasan atau ide yang melimpah dan terbarukan, f) kreativitas yang digali dari corak budaya lokal, g) sikap kehati-hatian dalam/memutuskan urusan bisnis, h) locus of control internal: usaha keras pribadi untuk berhasil; i) optimisme pada perbaikan iklim industri dan pasar sasaran, j) pro-aktif mengikuti tren desain produk yang berkembang di pasar, k) mengapresiasi keterampilan pekerja seni dengan reward pantas, l) proaktif menggunakan media internet dan teknologi untuk belajar, m) 
komitmen mandiri pada desain dan anti plagiasi, n) manajemen tim, mitra dan rekan kerja serta o) mengelola risiko dan kegagalan.

\section{Kinerja Usaha}

Saat ini belum ada kesepakatan yang dapat diterima secara universal mengenai praktek terbaik dalam mengukur kinerja usaha, karena kinerja harus mencerminkan informasi nonkeuangan yang relevan berdasarkan faktor kunci keberhasilan bisnis masing-masing (Clarke 1995 dan Gomes et al. 2004). Pada sisi lain kinerja harus didasarkan pada tujuan organisasi, kekritisan faktor sukses kebutuhan pelanggan, serta adanya monitoring terhadap aspek keuangan dan non keuangan (Manoochehri 1999). Kinerja akan dapat diukur dan berubah dengan strategi yang dinamis (Bhimani 1993). Demikian juga langkah-langkah keuangan dan nonkeuangan harus selaras dan sesuai dalam kerangka kerja strategis (Drucker 1999; McNair dan Mosconi 1987). Kinerja nonkeuangan merupakan salah satu ukuran kinerja yang banyak digunakan, disamping ukuran kinerja berdasarkan anggaran. Kinerja non keuangan dapat diukur dengan nilai kepuasan pelanggan, kualitas produk dan perputaran rekrutmen tenaga kerja. Ukuran kinerja nonkeuangan seperti kepuasan pelanggan, kualitas produk atau pergantian karyawan sangat relevan dalam kasus di mana ukuran kinerja berbasis pasar tidak tersedia. Sebelum tahun 1990 umumnya kinerja manajer hanya diukur berdasarkan perspektif keuangan. Kinerja keuangan diukur berdasarkan informasi yang dihasilkan dari sistem akuntansi berjangka pendek, sehingga pengukuran kinerja yang berbasis keuangan lebih berfokus pada perwujudan jangka pendek dan mengabaikan perwujudan jangka panjang.

Banyak aspek yang harus dipertimbangkan untuk membentuk kerangka kajian kinerja wirausaha industri kreatif, karena platform organisasi yang tidak seragam, dimana faktanya banyak peneliti berfokus untuk merancang dan mengadopsi sistem pengukuran kinerja berdasarkan karakteristik organisasi secara spesifik (Beamon 1999). Analisis faktor penentu keberhasilan akan membantu untuk mengidentifikasi ukuran kinerja dan matriks (Wu 2009). Dalam penelitian ini ukuran kinerja usaha akan dikembangkan atas kinerja nonkeuangan dan kinerja finansial. Kinerja nonkeuangan seperti kepuasan pelanggan, nilai pasar, pangsa pasar dan kinerja finasial diukur dari kemampuan pelaku wirusaha industri kreatif melakukan investasi menengah dan jangka panjang.

\section{Hipotesis}

Orientasi kewirausahaan dan kompetensi pengetahuan pasar merupakan efek positif kapabilitas pemasaran dan kinerja pemasaran (Suryanita 2006), dimana kapabilitas kewirausahaan berpengaruh positif dan signifikan terhadap profitabilitas usaha. Profit margin yang lebih tinggi adalah hasil dari proses inovasi yang tepat, adanya kemampuan untuk selalu proaktif merespon perubahan pada lingkungan dan dimilikinya sikap wirausaha untuk berani mengambil risiko. Penelitian tersebut 
memberikan implikasi mengenai perlunya penumbuhan kesadaran yang lebih besar mengenai pentingnya kapabilitas kewirausahaan. Pada sisi lain, kesadaran akan perlunya bisnis yang berorientasi kewirausahaan akan mendorong langkah-langkah untuk semakin memfokuskan usaha memberikan respon bagi kebutuhan pelanggan dalam meningkatkan profitabilitas (Kumalaningrum 2012), sehingga secara tidak langsung orientasi wirausaha mempunyai pengaruh yang lebih besar terhadap kinerja usaha yang dimediasi oleh variabel komitmen perilaku. Proses orientasi wirausaha yang dikombinasikan dengan komitmen perilaku akan menjadi sumber potensial keunggulan daya saing (Lukiastuti 2012). Jiwa kewirausahaan dan kreativitas secara bersama-sama memberikan kontribusi atau pengaruh terhadap keberhasilan usaha (Lestari 2013). Diantara variabel independen, kreativitas memberikan pengaruh yang lebih besar terhadap keberhasilan usaha pada objek penelitian dibanding dengan aspek jiwa kewirausahaan. Hasil penelitian Pangeran (2013) menunjukkan bahwa orientasi kewirausahaan berpengaruh positif terhadap kapabilitas finansial dan kapabilitas keuangan berpengaruh pada kinerja finansial. Orientasi kewirausahaan memiliki efek tidak langsung, yang dimediasi oleh kapabilitas keuangan pada kinerja keuangan (Pangeran 2013). Selanjutnya dalam penelitian ini akan ditarik hipotesis bahwa faktor-faktor pembentuk kapabilitas kewirausahaan industri kreatif memiliki pengaruh signifikan dengan kinerja usaha, ditunjukkan Gambar 2.

H1: Faktor-faktor pembentuk kapabilitas wirausaha industri kreatif nasional $\left(\mathrm{ENT}_{\mathrm{a}}, \mathrm{ENT}_{\mathrm{b}}, \mathrm{ENT}-\mathrm{ke}_{(\mathrm{n})}\right)$ berpengaruh positif pada kinerja usaha industri kreatif nasional.

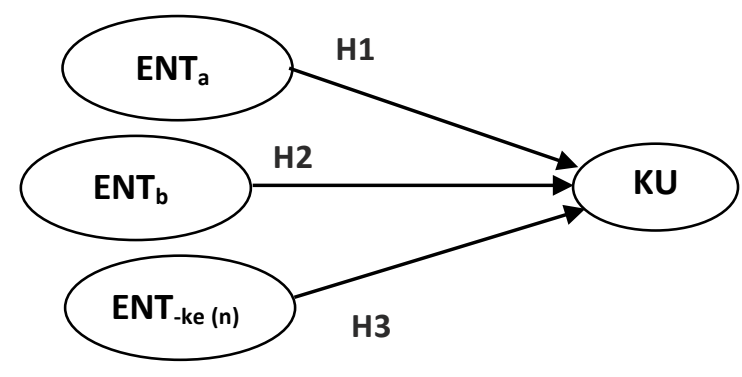

Gambar 1

Model Penelitian

\section{METODA PENELITIAN}

\section{Sampel dan Data Penelitian}

Populasi industri kreatif nasional adalah industri yang berorientasi pada penciptaan nilai kreatif. Berdasarkan data Statistik BPS pada tahun 2006 terdapat industri kreatif sebanyak 1.520 .759 perusahaan dengan laju pertumbuhan pertahun 7,70 persen, sehingga tahun 2013 jumlah populasi industri kreatif nasional adalah sebesar 1.872.054 perusahaan. Sampel penelitian industri kreatif nasional diambil 
dari tiga kota kreatif yang mewakili delapan dari empat belas subsektor industri kreatif di Indonesia. Sampel adalah sebagian dari populasi yang karakteristiknya hendak diselidiki, dan dianggap dapat mewakili keseluruhan populasi (Djarwanto 1996). Untuk memberikan hasil yang akurat, jumlah sampel yang diambil menggunakan rumus Slovin (Umar 2002), dengan tingkat toleransi sebesar 10 persen. Berdasarkan rumus Slovin tersebut kelayakan sampel dalam penelitian kewirausahaan industri kreatif ini adalah 100 responden, dengan teknik pengumpulan sampel menggunakan metode purposive random sampling.

Tabel 1

Pemilihan Objek Kota dan Sektor Sampel

\begin{tabular}{|c|c|c|c|c|c|c|c|c|c|c|}
\hline \multirow[b]{2}{*}{$\begin{array}{c}\text { Kota } \\
\text { Kreatif } \\
\text { Nasional }\end{array}$} & \multicolumn{9}{|c|}{ Sektor Industri Kreatif } & \multirow[b]{2}{*}{ Total } \\
\hline & $A d v$. & Arsitektur & Fashion & $\begin{array}{c}\text { Movie } \\
\text { dan } \\
\text { Photo }\end{array}$ & Game & Penerbitan & $\begin{array}{l}\text { Piranti } \\
\text { Lunak }\end{array}$ & Televisi & Craft & \\
\hline Surakarta & 8 & 4 & 3 & 5 & 1 & 6 & 0 & 7 & 1 & $\begin{array}{c}3 \\
31 \%\end{array}$ \\
\hline Denpasar & 3 & 4 & 4 & 6 & 0 & 7 & 8 & 1 & 0 & $\begin{array}{c}33 \\
29,2 \%\end{array}$ \\
\hline Yogyakarta & 5 & 0 & 2 & 13 & 1 & 12 & 4 & 0 & 8 & $\begin{array}{c}45 \\
39,8 \%\end{array}$ \\
\hline TTol & 16 & 8 & 9 & 24 & 2 & 25 & 12 & 8 & 9 & 113 \\
\hline & $14,2 \%$ & $7,1 \%$ & $8 \%$ & $21,2 \%$ & $1,8 \%$ & $22,1 \%$ & $10,6 \%$ & $7,1 \%$ & $8 \%$ & $100 \%$ \\
\hline
\end{tabular}

Sumber: Data penelitian, 2014

Alat Analisis

Secara sederhana tujuan analisis faktor adalah untuk menentukan beberapa buah faktor (variabel) sedemikian rupa sehingga data multivariat dengan komponen yang cukup banyak dapat dijelaskan atau dipelajari dengan memakai data berdasarkan beberapa faktor (variabel) terpilih (Hair 1995).

Model analisis faktor:

$X_{i k}=\lambda_{i 1} f_{1 k}+\lambda_{i 2} f_{2 k}+\ldots . .+\lambda_{i 2} f_{2 k}+e_{i k}$

Keterangan:

$X_{i k}=$ nilai dari variabel kewirausahaan ke-i untuk observasi ke-k.

$f_{1 k}=$ nilai dari faktor kewirusahaa ke-j untuk observasi ke-k (disebut juga factor scores).

$\lambda_{i 1}=$ hubungan dari variabel ke-i dengan faktor ke-j, dimana ada $\mathrm{m}$ faktor dan $\mathrm{p}$ variabel, $\mathrm{m}<\mathrm{p}$.

Secara praktis dalam penelitian ini, analisis faktor digunakan untuk mengekstraksi sekian banyak variabel yang dikembangkan menjadi hanya beberapa variabel saja sehingga lebih mudah diamati secara lebih sederhana. Analisis faktor juga akan menghasilkan urutan kepentingan dari seluruh variabel yang terbentuk. Metoda ini membantu menemukan model, kelompok variabel dari pelaku kewirausahaan yang harus diperhatikan lebih dulu bagi pengembangan kewirausahaan industri kreatif dan dampaknya pada kinerja usaha. 
Model regresi linier berganda dalam penelitian ini digunakan untuk mengkaji variabel-variabel yang difaktorkan dalam analisis faktor, untuk diuji pengaruhnya terhadap variabel dependen kinerja usaha, dalam model penelitian ditunjukkan oleh persamaan berikut:

$$
\mathrm{KU}=\alpha+\beta_{1} \mathrm{ENT}_{\mathrm{a}}+\beta_{2} \mathrm{ENT}_{\mathrm{b}}+\beta_{3} \mathrm{ENT}_{-\mathrm{n}}+\varepsilon
$$

Keterangan:

$\alpha \quad=$ konstanta

$\mathrm{ENT}_{\mathrm{a}}=$ faktor 1 kapablitas kewirausaan.

$\mathrm{ENT}_{\mathrm{b}}=$ faktor 2 kapabilitas kewirausaan.

ENT $_{-\mathrm{n}}=$ faktor ke-n kapabilitas kewirausaan.

$\mathrm{KU} \quad=$ kinerja usaha

$\varepsilon \quad=$ error

\section{PEMBAHASAN}

\section{Analisis Statistik Deskriptif}

Berdasarkan Tabel 2, variabel kapabilitas kewirausahaan (ENT) memiliki nilai maksimal 145 persen, minimal 73 dan rerata 108,34. Data memiliki simpangan baku sebesar 13,52. Sementara sebaran data kinerja usaha (KU) memiliki nilai maksimum 75, nilai minimum 33, rerata 58,84 serta simpangan baku sebesar 9,18. Kedua data berdistribusi normal.

Tabel 2

Statistik Deskriptif

\begin{tabular}{lccccc}
\hline & N & Minimum & Maksimum & Rerata & Simpangan Baku \\
\hline Kapabiltas kewirausahaan & 113 & 73 & 141 & 108,34 & 13,532 \\
Kinerja usaha & 113 & 33 & 75 & 54,84 & 9,181 \\
Valid N (listwise) & 113 & & & & \\
\hline
\end{tabular}

Sumber: Data penelitian, 2014

Uji normalitas data kapabilitas kewirausahaan (ENT) diukur dengan menggunakan besaran nilai Kolmogorov-Smirnov. Pengujian Kolmogorov-Smirnov diperoleh besaran 0,09 dan nilai Sig. 2,0, jauh diatas toleransi yang digunakan dalam penelitian (0.05). Demikian pula untuk data kinerja usaha (KU) memiliki besaran Kolmogorov-Smirnov 0,065 dan Sig. 0,2, sehingga secara statistik kedua variabel (ENT dan KU) yang dimasukkan dalam model berdistribusi normal.

\section{Analisis Faktor Kapabilitas Kewirausahaan Industri Kreatif}

Dalam analisis faktor, variabel akan mengelompok jika variabel tersebut berkorelasi dengan variabel lain yang masuk dalam kelompok faktor tertentu. Data kapabilitas kewirusahaan industri kreatif yang akan dianalisis faktor, harus memiliki nilai anti-image correlation diatas 0,5. Hal ini akan memberikan maksud bahwa semua variabel tentang kapabilitas perilaku kewirausahaan industri kreatif layak untuk dianalisis faktor. Hasil uji anti-image correlation pada 15 variabel yang diuji 
dalam model dan semua variabel tersebut memiliki nilai diatas 0,5 dengan interval 0,604-0,870. Uji kecukupan sampel dilakukan melalui nilai Kaiser Meyer Olkin Measure of Sampling Adequacy (KMO), Nilai KMO data adalah sebesar 0,783 lebih besar dari 0,5. Hal ini berarti bahwa sampel yang diambil yaitu sebanyak 113 responden dari ketiga kota kreatif nasional dengan unit variabel sebanyak 15 variabel, cukup layak untuk dianalisis. Angka Bartlett's Test of Sphericity $=469,517$ dan Sig. $=$ 0,000 menunjukkan bahwa matriks korelasi bukan merupakan matriks identitas, sehingga layak untuk di analisis faktor.

Dari hasil analisis faktor yang didasarkan pada Eigen values yang lebih besar atau sama dengan satu, diperoleh sebanyak tiga faktor. Nilai persentase kumulatif untuk ketiga faktor tersebut sebesar 51,83 persen, yang berarti bahwa ketiga faktor yang terbentuk mampu menerangkan data multivariat 15 variabel sebesar 51,83 persen. Variabel merupakan masing-masing faktor yang disajikan dalam Tabel 3.

Tabel 3

Rotated Component Matrix Kapabilitas Kewirausahaan

\begin{tabular}{lccc}
\hline \multirow{2}{*}{ Kapabilitas Kewirausahaan } & \multicolumn{2}{c}{ Komponen Faktor } \\
\cline { 2 - 4 } & $\mathbf{1}$ & $\mathbf{2}$ & $\mathbf{3}$ \\
\hline inovasi menciptakan daya beda & 0,469 & 0,044 & 0,680 \\
inovasi membuat desain yang belum pernah ada & 0,772 & 0,232 & 0,123 \\
komitemen memenuhi desain kontrak kerja & 0,689 & 0,123 & 0,120 \\
komitmen pemenuhan waktu deadline & 0,672 & 0,024 & $-0,287$ \\
gagasan, ide yang melimpah selalu terbarukan & $-0,374$ & 0,343 & 0,513 \\
kreatifitas yang digali dari corak budaya kuat sekitar & 0,036 & 0,781 & $-0,230$ \\
sikap kehati-talian bertindak/memutukan urusan bisnis & 0,470 & $-0,159$ & 0,045 \\
locus of control internal: usaha keras pribadi untuk berhasil & 0,181 & 0,627 & $-0,021$ \\
otimisme pada industri dan pasar sasaran & 0,748 & 0,087 & 0,248 \\
proaktif mengikuti trend desain yang berkembang & 0,558 & 0,017 & $-0,439$ \\
mengapresiasi keterampilan SDM dengan reward pantas & 0,175 & $-0,634$ & $-0,134$ \\
proaktif menggunakan media internet untuk belajar & 0,713 & $-0,008$ & 0,171 \\
komitmen mandiri desain dan anti plagiasi & $-0,132$ & 0,660 & $-0,097$ \\
manajemen tim dan bawahan dan mitra kerja & 0,609 & $-0,372$ & 0,003 \\
mengelola manajemen risiko dan kegagalan & 0,525 & 0,224 & $-0,332$ \\
\hline Sumber: Data penelitian, 2014 & & &
\end{tabular}

Sumber: Data penelitian, 2014

Matriks rotasi komponen membentuk tiga faktor, dengan kelompok komponen faktor 1 meliputi: a) inovasi membuat desain yang belum pernah ada (loading faktor 0,772); b) komitmen memenuhi desain kontrak kerja (loading factor 0,689); c) komitmen pemenuhan waktu deadline (loading faktor 0,672); d) sikap kehati-hatian bertindak (loading faktor 0,470); e) optimisme pada permintaan pasar (loading faktor 0,748); f) proaktif mengikuti tren desain yang berkembang (loading faktor 0,558); g) proaktif menggunakan media internet untuk belajar (loading faktor 0,713); h) manajemen tim dan rekan kerja (loading faktor 0,609). Kelompok faktor 2 berisikan empat faktor, meliputi: a) kreatifitas yang digali dari corak budaya kuat 
sekitar (loading factor 0,781); b) locus of control internal (loading factor 0,627); c) mengapresiasi keterampilan SDM dengan reward pantas (loading factor 0,634); d) komitmen mandiri desain dan anti plagiasi (loading factor 0,660) dan faktor 3 meliputi: a) inovasi menciptakan daya beda (loading factor 0,680); b) gagasan, ide yang melimpah selalu terbarukan (loading factor 0,513).

Untuk melakukan analisis pada langkah selanjutnya, maka variabel dari aspek kapabilitas kewirausahaan yang terbentuk tersebut selanjutnya akan dikonversi menjadi satu kelompok variabel yang berupa faktor utama. Kapabilitas kewirausahaan industri kreatif nasional dalam penelitian ini secara empiris telah terbentuk menjadi tiga faktor utama, yaitu pengelolaan internal dan manajemen risiko (faktor 1); kemandirian desain dan anti plagiasi (faktor 2) serta daya beda unik dan ide yang selalu terbarukan (faktor 3).

\section{Analisis Regresi Kapabilitas Kewirausahaan terhadap Kinerja Usaha Industri Kreatif}

Pengujian atas hipotesis dilakukan dengan melakukan analisis regresi berganda pada faktor-faktor yang dibentuk kapabilitas kewirausahaan (ENT) terhadap kinerja usaha (KU). Definisi operasional merujuk pada model Gambar 1, dimana dalam model terdapat tiga variabel independen dan satu variabel dependen. Variabel independen pengelolaan internal dan manajemen risiko $\left(\mathrm{ENT}_{\mathrm{a}}\right)$, kemandirian desain dan anti plagiasi $\left(\mathrm{ENT}_{\mathrm{b}}\right)$ serta daya beda unik dan ide yang selalu terbarukan $\left(\mathrm{ENT}_{\mathrm{c}}\right)$. Sedangkan variabel dependen adalah kinerja usaha (KU). Keempat variabel yang diteliti memiliki skala rasio dan berdistribusi normal, sehingga model memiliki kelayakan empiris untuk diukur dengan kajian statistik parametrik regresi berganda. Hasil pengujian hipotesis (ANOVA-Uji F) untuk membuktikan pengaruh kapabilitas kewirausahaan secara simultan terhadap kinerja usaha.

Dari analisis ANOVA (Tabel 6) diperoleh nilai Uji F sebesar 12,815 dan sig. 0,000; karena nilai sig. masih berada dibawah alfa $(0,05)$, maka H0 ditolak dan H1 diterima. Hal ini berarti variabel independen yang merupakan manifestasi dari faktorfaktor pembentuk kapabilitas kewirausahaan industri kreatif berupa variabel $\mathrm{ENT}_{\mathrm{a}}$, $\mathrm{ENT}_{\mathrm{b}}$ dan $\mathrm{ENT}_{\mathrm{c}}$ secara simultan memiliki pengaruh signifikan terhadap kinerja usaha. Hal ini sejalan dengan beberapa peneliti sebelumnya seperti kajian yang dilakukan oleh Suryanita 2006; Kumalaningrum 2012; Lukiastuti 2012; Lestari 2013 dan Pangeran 2013, bahwa kapabilitas maupun orientasi kewirausahaan berpengaruh postif terhadap kinerja usaha.

Pada pengukuran analisis pengaruh secara parsial (uji t): untuk menguji hipotesis pengaruh $\mathrm{ENT}_{\mathrm{a}}$ terhadap KU, diperoleh angka t-hitung 3,229 (Sig. 0,000). Nilai ini H0 ditolak dan H1a diterima, yang berarti ada pengaruh signifikan anatara kapabilitas pengelolaan internal manajemen risiko kewirausahaan terhadap kinerja usaha industri kreatif. Demikian juga pada pengukuran pengaruh $\mathrm{ENT}_{\mathrm{c}}$ terhadap $\mathrm{KU}$ 
yang memiliki angka t-hitung 5,669 (sig. 0,017) < 0,05, artinya H1 diterima dengan interpretasi ada pengaruh signifikan antara kapabilitas daya beda produk dan gagasan ide yang selalu terbarukan terhadap kinerja usaha. pada pengukuran pengaruh $\mathrm{ENT}_{\mathrm{b}}$ terhadap KU yang memiliki angka uji t-hitung -0,33 (sig. 0,742) > 0,05, artinya H0 diterima dengan interpretasi tidak ada pengaruh signifikan antara kapabilitas kemandirian anti plagiasi desain produk terhadap kinerja usaha.

Merujuk pada nilai standardized coefficients beta, diperoleh gambaran bahwa terdapat dominasi dari ketiga variabel dependen yang mewakili faktor-faktor pembentuk kapabilitas kewirausahaan industri kreatif nasional tersebut. Faktor pengelolaan internal dan manajemen risiko $\left(\mathrm{ENT}_{\mathrm{a}}\right)$ merupakan faktor dominan, disusul faktor daya beda produk dan gagasan ide yang selalu terbarukan $\left(\mathrm{ENT}_{\mathrm{c}}\right)$ serta terakhir faktor kemandirian anti plagiasi desain produk $\left(\mathrm{ENT}_{\mathrm{b}}\right)$. Merujuk pada formula persamaan (1), selanjutnya didapatkan rumusan model regresi linier berganda $\mathrm{KU}=0,405 \mathrm{ENT}_{\mathrm{a}}-0,046 \mathrm{ENT}_{\mathrm{b}}+0,558 \mathrm{ENT}_{\mathrm{c}}+21,062$. Pada fakta model persamaan regresi yang dihasilkan serta pengujian hipotesis secara parsial uji-t, variabel $\mathrm{ENT}_{\mathrm{a}}$ dan $\mathrm{ENT}_{\mathrm{c}}$ memiliki implikasi yang sama dengan sejumlah penelitian sebelumnya yang mendukung premis hipotesis penelitian mengenai adanya pengaruh signifikan positif dari kapabilitas kewirausahaan terhadap kinerja usaha. Namun pada sisi lain, variabel ENT $_{\mathrm{b}}$ yang merupakan manifestasi dari faktor kemandirian dan anti plagiasi desain produk mengindikasikan adanya hubungan terbalik antara dan tidak dijumpai pengaruh yang signifikan terhadap kinerja usaha. Kendati wirausaha industri kreatif nasional telah memahami semangat ekonomi kreatif dan nilai-nilai faktor penggerak industri berupa gagasan, ide, pemikiran sebagai modal dalam industri kreatif (59,3 persen), namun kapabilitas kewirausahaan dari sisi kemandirian desain dan semangat anti plagiasi (ENT ${ }_{b}$ ) belum memberikan dampak secara nyata pada kinerja. Meskipun demikian, sebagian besar responden berkomitmen untuk berusaha tidak menjiplak ide dan produk orang lain (66,5 persen).
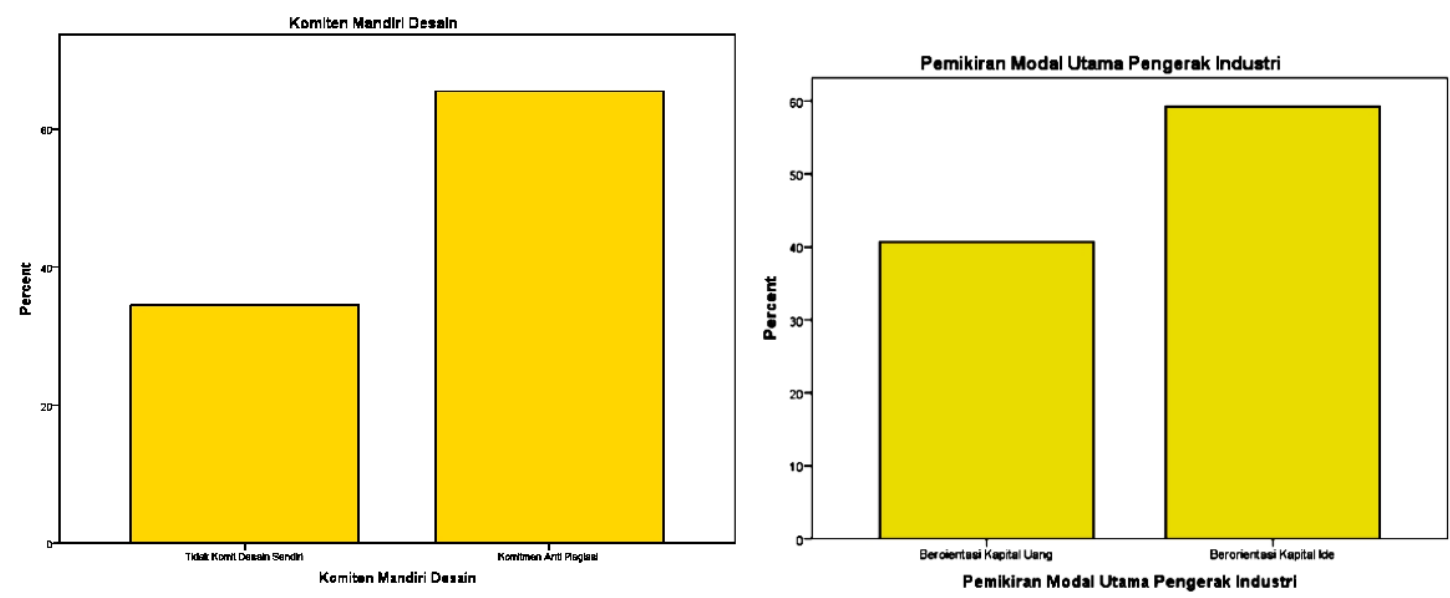

Gambar 2

Modal Utama Penggerak Industri 
Aspek lain yang menyebabkan munculnya hubungan terbalik pada variabel independen $\mathrm{ENT}_{\mathrm{b}}$ terhadap variabel dependen KU adalah rendahnya locus of control internal dari wirausaha industri kreatif. Pengukuran aspek locus of control wirausaha industri kreatif dalam observasi data sampel memberikan gambaran adanya dominasi locus of control eksternal (54,9\%) dibandingkan locus of control internal (45,1 persen) dari pelaku wirausaha industri kreatif.

Locus of control eksternal menimbulkan kuatnya karakter kepasrahan pelaku wirausaha industri kreatif nasional pada nasib atas usaha bisnis yang mereka jalankan. Aspek locus of control eksternal pelaku wirausaha akan memberikan ilustrasi alam berpikir mereka: sehebat apapun usaha dan perencanaan yang dilakukan, pada akhirnya tetap berakhir pada ada tidaknya nasib baik dan keberuntungan. Hasil observasi berupa wawancara langsung pada sejumlah sampel untuk dikonfirmasi, ditemukan bahwa sebagian dari mereka memiliki alam pemikiran filosofi yang telah mengakar kuat, yaitu: “wong pinter kalah karo wong bejo", sehingga mereka memutuskan bekerja "samadyo" atau bekerja sekuat dan sebisa yang mereka lakukan, setelah itu nasib yang akan menentukan usaha mereka. Belum ditemukan penelitian sebelumnya dan kaidah teoritis yang menjelaskan adanya hubungan negatif antara $\mathrm{ENT}_{\mathrm{b}}$ terhadap $\mathrm{KU}$, namun fakta deskripif dalam penelitian ini memberikan gambaran rendahnya locus of control internal sebagai input model akan memberikan kontribusi dampak hubungan terbalik bagi kinerja usaha.

\section{SIMPULAN, KETERBATASAN DAN IMPLIKASI}

\section{Simpulan}

Beberapa simpulan yang dapat ditarik dalam ruang lingkup penelitian mengenai faktor-faktor pembentuk kapabilitas wirausaha industri kreatif dan dampaknya pada kinerja usaha akan merujuk pada tiga poin permasalahan sebagai simpulan dalam penelitian ini.

1. Penelitian ini merumuskan tiga faktor pembentuk kapabilitas kewirausahaan industri kreatif melalui alat analisis statistik berupa analisis faktor. Faktor-faktor yang terbentuk memiliki Eigen-value sama atau diatas 1, meliputi: pengelolaan internal dan manajemen risiko (faktor 1); kemandirian desain dan anti plagiasi (faktor 2) serta daya beda unik dan ide yang selalu terbarukan (faktor 3). Ketiga faktor yang didefinisikan dapat menjadi rujukan penelitian selanjutnya dan merupakan poin kunci dalam pengembangan karakter sumber daya manusia, berupa subjek individu pelaku kewirausahaan industri kreatif nasional.

2. Analisis ANOVA memberikan bukti empiris adanya pengaruh signifikan dari kapabilitas karakter kewirausahaan industri kreatif terhadap kinerja usaha mereka. Hal ini memperkuat temuan-temuan peneliti sebelumnya, bahwa kapabilitas 
kewirausahaan memberikan dampak positif bagi kinerja usaha. Dari ketiga faktor yang membentuk kapabilitas wirusaha di atas, faktor pengelolaan internal dan manajemen risiko merupakan faktor dominan yang menentukan kinerja usaha industri kreatif nasional.

3. Temuan deskriptif penelitian menunjukkan pelaku wirausaha Indonesia telah memahami konsep, bahwa: gagasan, ide dan pengetahuan merupakan modal utama penggerak industri dalam paradigma fase ekonomi kreatif. Pelaku kewirausahaan kreatif nasional juga sudah memahami pentingnya kemandirian desain, anti plagiasi dan memberikan apresiasi atas kekayaan intelektual produk lain. Namun pada sisi lain sebagian dari pelaku wirausaha memiliki locus of control eksternal yang dominan, dimana sebagian besar sampel yang dikonfirmasi melalui observasi memiliki pola alam berpikir: bahwa sehebat apapun seorang wirausaha berusaha pada akhirnya akan tetap menyerah pada ada tidaknya nasib baik. Kapabilitas wirausaha yang matang sekalipun dalam usaha dan perencanaan masih akan bergantung pada keberuntungan yang dimilikinya. Dalam konteks "berusaha” dan "wirausaha” hal tersebut memberikan makna konotasi negatif.

\section{Keterbatasan dan Saran}

Penelitian ini mencakup delapan sektor dari 15 sektor industri kreatif saat ini, dengan objek hanya pada tiga kota kreatif yaitu Denpasar, Yogyakarta dan Surakarta, sehingga dengan keterbatasan ini, saran yang dikemukakan adalah perlu adanya kajian pembanding yang mengkomparasikan dan mengkonfirmasi temuan dengan mereplikasi penelitian ini pada ruang lingkup sampel yang lebih luas untuk mendapatkan deskripsi model secara utuh. Keterbatasan lainnya adalah pengukuran penelitian sepenuhnya berdasarkan pada pengukuran subjektif persepsi para pemilik dan pengambil keputusan kewirausahaan industri kreatif, meskipun dalam banyak penelitian, pengukuran secara subjektif seperti ini masih dibenarkan dalam kaidah metodologis, namun tetap menciptakan potensi bias. Pada sisi lain, munculnya temuan locus of control eksternal yang dominan pada wirausaha industri kreatif nasional diprediksi akan menjadi faktor penghambat dan berpotensi menimbulkan dampak negatif pada kinerja industri. Selanjutnya ranah karakter psikologis ini membutuhkan kajian empiris untuk mengungkap dampak locus of control eksternal dari pelaku kewirausahaan industri kreatif nasional dalam suatu kajian studi lebih lanjut.

\section{Implikasi}

Penelitian ini memiliki dua implikasi, yaitu bagi pelaku bisnis dan pembuat regulasi. Implikasi bagi pelaku bisnis kewirusahaan industri kreatif untuk mengembangkan ketiga faktor kunci, berupa pengelolaan internal dan manajemen risiko; kemandirian desain anti plagiasi; serta kapabilitas untuk menciptakan daya beda dan ide yang selalu terbarukan pada produk kreatif. Namun dari ketiga faktor tersebut, faktor dominan adalah pengelolaan internal dan manajemen risiko, dimana 
pelaku wirausaha industri kreatif meningkatkan kinerja usaha dengan melempar produk-produk kreatif baru, hal yang harus bersamaan dilakukan adalah manajemen risiko dengan mengontrol probabilitas risiko yang berpotensi muncul. Manajemen risiko yang baik akan memiliki dampak pada kinerja usaha kewirusahaan industri kreatif. Implikasi bagi pembuat regulasi peta jalan industri kreatif, deskripsi kondisi sekarang memberikan fakta empiris bahwa wirausaha Indonesia telah memahami konsep ekonomi kreatif yang menekankan ide, gagasan dan pengetahuan sebagai model utama, munculnya semangat untuk menciptakan desain mandiri yang berakar dari kearifan budaya disekitarnya, serta mulai munculnya kesadaran kekayaan intelektual atas produk melalui semangat anti-plagiasi desain. Deskripsi pemahaman dari pelaku wirausaha yang demikian adalah merupakan aset bangsa dalam ekonomi kreatif yang menjadi dasar pengembangan kapabilitas wirausaha inovatif dan kreatif dengan ditopang dengan regulasi pemerintah dalam bidang sumber daya manusia, sehingga ujungnya akan memicu akselerasi industri kreatif nasional.

\section{DAFTAR PUSTAKA}

Beamon, B. M. 1999. Measuring supply chain performance. International Journal of Operations \& Production Management. Vol.19: 275-92.

Bhimani, A. 1993. Performance measures in UK manufacturing companies: The state of play, in management accounting. Vol.71 No.11: 20-2.

BPS. 2009. Tabel Prosentase Kontribusi Indutri Kreatif terhadap PDB Nasional. Diolah dari Statistik Indonesia \& Statisik Industri BPS. Available at www.indonesiakreatif.net.

Carlson, N. R., C. D. Heth, H. Miller, J. W. Donahoe, W. Buskist, dan G. N. Martia. 2007. Psychology: The Science of Behaviour. $6^{\text {th }}$ Ed. Boston: Pearson. Allyn and Bacon.

Clarke, P. 1995. Non-financial measures of performance in management. Accountancy Ireland. Vol.27 No.2: 22-4. . 2009. Pengembangan Industri Kreatif menuju Visi Ekonomi Kreatif 2025: Rencana Pengembangan 14 Subsektor Industri Kreatif, Kelompok Kerja Indonesia Design Power. Departemen Perdagangan Republik Indonesia. 2009. Rencana Kerja Pengembangan Ekonomi Kreatif Indonesia 20092015. Kelompok Departemen Perdagangan Republik Indonesia.

Djarwanto. 1996. Mengenal Beberapa Uji Statistik dalam Penelitian. Edisi Pertama. Liberty: Yogyakarta.

Drucker, P. F. 1985. Innovation and Entrepreneurship: Practice and Principles. New York, USA: Harper Business. 
Drucker, P. F. 1999. The Discipline of Innovation. In Review, Harvard Business, editor, Harvard Business Review on Breakthrough Thinking. Boston: Harvard Business Review Paperbacks.

Florida, R. 2002. The Rise of the Creative Class: And How it's transforming work, leisure, community and everyday life. New York: Perseus Book Group.

Gomes, C. F., M. M. Yasin, dan J. V. Lisboa. 2004. A literature review of manufacturing performance measures and measurement in an organizational context: a framework and direction for future research. Journal of Manufacturing Technology Management. Vol.15 No.6: 511-530.

Halim, A. S. A., S. Muda., dan W. A. Aziz. 2011. Locus of control: a basis for creative entrepreneurs in kraftangan Malaysia. Jminternational journal of $\mathrm{HR}$ Review. Vol.1 No.1. Availbale at www.jmijitm.com.

Hesmondhalgh, D. 2002. The Cultural Industries. SAGE on Wikipedia creative industries definition.

HKU. 2010. The entrepreneurial dimension of the cultural and creative industries. utrecht school of the arts (Hogeschool voor de Kunsten Utrecht, HKU) in the Netherland. Available at creativwirtschaft.at.

Indonesia Kreatif. 2013. Kontribusi Ekonomi Kreatif terhadap PDB Indonesia 20102013. Available at program.indonesiakreatif.net.

Iwan H., V. S Tripriyo, dan S. B. Harnomo. 2014. Knowledge management capability rooted on information technology and cultural heritage environment synergy to develop national creative industry competitiveness. Proceeding International Conference Unnes. ISSN: 2355-3456.

Kumalaningrum, P. M. 2012. Kapabilitas kewirausahaan dan profitabilitas: Peran moderasi fleksibilitas strategi. Jurnal Riset Akuntansi dan Keuangan. Vol.8 No.2. Available at jrmb.ukdw.ac.id.

Landry, C., dan F. Bianchini. 1995. The Creative City. London: Demos.

Lestari, F. 2013. Pengaruh jiwa kewirausahaan dan kreativitas terhadap keberhasilan usaha pada sentra industri rajutan Binong Jati Bandung. Available at elib.unikom.ac.id.

Lukiastuti, F. 2012. Pengaruh orientasi wirausaha dan kapabilitas jejaring usaha terhadap peningkatan kinerja ukm dengan komitmen perilaku sebagai variabel interviening (Studi empiris pada sentra UKM batik di Sragen, Jawa Tengah). Available at www.lppm.ut.ac.id.

Manoochehri, G. 1999. The road to manufacturing excellence: Using performance measures to become world-class. Industrial Management: 7-13. 
McNair, C. J., dan W. Mosconi. 1987. Measuring performance in an advanced manufacturing environment. Management Accounting Vol.69 No.1: 28.

Perminas, P. 2013. Orientasi kewirausahaan dan kinerja keuangan usaha mikro dan kecil: peran mediasi kapabilitas keuangan. Jurnal Ekonomi dan Bisnis. Vol.7 No.1 (Maret): 1978-3116. Available at www.researchgate.net.

Prawirokusumo. 1997. Small Business and Entrepreneurship. Prentice Hall.

Rotter, J. B. 1954. Social Learning And Clinical Psychology. New York: PrenticeHall.

Singh, S., dan J .D. McKeen. 2006. Knowledge management capability and organizational performance: A theoretical foundation. Conference at the University of Warwick. (March): 1 -54.

Simatupang, T. M. 2008. Perkembangan Industri Kreatif. Sekolah Bisnis dan Manajemen. Institut Teknologi Bandung.

Suryanita, A. 2006. Analisis pengaruh orientasi kewirausahaan dan kompetensi pengetahuan terhadap kapabilitas untuk meningkatkan kinerja pemasaran. Available at eprints.undip.ac.id.

Tofler, A. 1970. Future Shock. Amerika: Random House.

Wiklund, J., dan D. Shepherd. 2005. Entrepreneurial orientation and small business performance: A configurational approach. Journal of Business Venturing. Vol.20: 71-91.

Wu, D. 2009. Measuring performance in small and medium enterprises in the information \& communication technology industries. Tesis. Available at researchbank.rmit.edu.au. 


\section{LAMPIRAN}

Tabel 3

Uji KMO and Bartlett's Test

\begin{tabular}{lll}
\hline Kaiser-Meyer-Olkin Measure of Sampling Adequacy. & 0,783 \\
\cline { 2 - 3 } Bartlett's Test & Approx. Chi-Square & 469,517 \\
& df & 105 \\
Sig. & 0,000 \\
\hline
\end{tabular}

Tabel 4

Total Variance Explained Variabel Kapablitas Kewirausahaan

\begin{tabular}{|c|c|c|c|c|c|c|c|c|c|}
\hline \multirow[t]{2}{*}{ Komponen } & \multicolumn{3}{|c|}{ Initial Eigen values } & \multicolumn{3}{|c|}{$\begin{array}{l}\text { Extraction Sums of Squared } \\
\text { Loadings }\end{array}$} & \multicolumn{3}{|c|}{$\begin{array}{c}\text { Rotation Sums of Squared } \\
\text { Loadings }\end{array}$} \\
\hline & Total & Variance & Kumulatif & Total & Variance & Kumulatif & Total & Variance & Kumulatif \\
\hline 1 & 4.210 & 28.064 & 28.064 & 4.210 & 28.064 & 28.064 & 3.307 & 22.048 & 22.048 \\
\hline 2 & 2.251 & 15.005 & 43.070 & 2.251 & 15.005 & 43.070 & 2.246 & 14.973 & 37.022 \\
\hline 3 & 1.314 & 8.761 & 51.831 & 1.314 & 8.761 & 51.831 & 2.221 & 14.809 & 51.831 \\
\hline 4 & 0.991 & 6.608 & 58.439 & & & & & & \\
\hline 5 & 0.892 & 5.948 & 64.387 & & & & & & \\
\hline 6 & 0.886 & 5.910 & 70.296 & & & & & & \\
\hline 7 & 0.764 & 5.096 & 75.393 & & & & & & \\
\hline 8 & 0.654 & 4.362 & 79.754 & & & & & & \\
\hline 9 & 0.626 & 4.176 & 83.930 & & & & & & \\
\hline 10 & 0.525 & 3.500 & 87.431 & & & & & & \\
\hline 11 & 0.495 & 3.302 & 90.733 & & & & & & \\
\hline 12 & 0.442 & 2.950 & 93.683 & & & & & & \\
\hline 13 & 0.343 & 2.287 & 95.970 & & & & & & \\
\hline 14 & 0.307 & 2.048 & 98.018 & & & & & & \\
\hline 15 & 0.297 & 1.982 & 100.000 & & & & & & \\
\hline
\end{tabular}

Extraction Method: Principal Component Analysis.

Tabel 6

Hasil Uji ANOVA

\begin{tabular}{lccccc}
\hline Model & Sum of Squares & $\boldsymbol{d} \boldsymbol{f}$ & Mean Square & $\boldsymbol{F}$ & Sig. \\
\hline Regression & 2507,440 & 3 & 835,813 & 12,815 & $0,000 \mathrm{~b}$ \\
Residual & 6848,009 & 105 & 65,219 & & \\
Total & 9355,450 & 108 & & & \\
\hline
\end{tabular}


Tabel 7

Model Regresi Berganda

\begin{tabular}{|c|c|c|c|c|c|}
\hline \multirow[t]{2}{*}{ Model } & \multicolumn{2}{|c|}{$\begin{array}{l}\text { Unstandardized } \\
\text { Coefficients }\end{array}$} & \multirow{2}{*}{$\begin{array}{c}\begin{array}{c}\text { Standardized } \\
\text { Coefficients }\end{array} \\
\text { Beta }\end{array}$} & \multirow[t]{2}{*}{$t$} & \multirow[t]{2}{*}{ Sig. } \\
\hline & B & Std. Error & & & \\
\hline (Constant) & 21,062 & 6,523 & & 3,229 & 0,002 \\
\hline Pengelolaan Internal dan Manajemen Risiko $\left(\mathrm{ENT}_{\mathrm{a}}\right)$ & 0,405 & 0,071 & 0,478 & 5,699 & 0,000 \\
\hline Kemandirian dan Anti Plagiasi Desain Produk $\left(\mathrm{ENT}_{\mathrm{b}}\right)$ & $-0,046$ & 0,140 & $-0,028$ &,- 330 & 0,742 \\
\hline $\begin{array}{l}\text { Daya Beda Produk dan Gagasan Ide yang Selalu } \\
\text { Terbarukan }\left(\mathrm{ENT}_{\mathrm{c}}\right)\end{array}$ & 0,558 & 0,230 & 0,202 & 2,423 & 0,017 \\
\hline
\end{tabular}

Tabel 8

Locus of Control Wirausaha Industri Kreatif

\begin{tabular}{llrrrr}
\hline & Frekuensi & Persen & Persen Valid & Persen Kumulatif \\
\cline { 3 - 5 } Valid & 62 & 54.9 & 54.9 & 54.9 \\
& Locus of Control Eksternal of Control Internal & 51 & 45.1 & 45.1 & 100.0 \\
& Total & 113 & 100.0 & 100.0 & \\
\hline
\end{tabular}

